http://dx.doi.org/10.4314/jae.v18i2.10

\title{
Agricultural Information Needs of Physically Challenged Farmers: A Case Study Of Leprosy Hospital, Etinan Local Government Area, Akwa Ibom State
}

\author{
Etuk, U. R. ${ }^{1}$, Uwak, G. ${ }^{1}$ and Jike-wai, $\mathbf{O}^{2}$ \\ ${ }^{1}$ Department of Agricultural Economics and Extension, University of Uyo, Uyo. Akwa Ibom \\ State \\ ${ }^{2}$ Department of Agricultural Economics and Extension, University of Port Harcourt, Rivers \\ State \\ unyrobet@yahoo.com. Phone no: 08068358894
}

\section{Abstract}

The study assessed the agricultural information needs of physically challenged farmers in Leprosy Hospital, Ekpene Obom, Etinan Local Government Area of Akwa Ibom State. The specific objectives were: to examine the socio-economic characteristics of the respondents, determine the sources of available agricultural information, ascertain the respondents' level of access to agricultural information, examine the agricultural information needs of the respondents in the study area. A two-stage sampling procedure was used to select fifty three (53) respondents for the study. Data were collected with well structured questionnaire and analyzed using factor analysis and cluster analysis. A factor analysis performed on the fourteen (14) sources of agricultural information yielded two (2) dimensions namely Individual Contact and Mass Contact factors; these accounted for $61 \%$ of the variation. Accessibility to agricultural information was low. Cluster analysis further grouped the respondents into four cluster levels (very high, high, low and very low accessed groups) in terms of access to agricultural information, with the very low accessed group consisting majority (66\%) of the respondents. A factor analysis was also performed for the thirty (30) agricultural information need variables. This operation produced nine (9) factors namely; Customized Innovation and Self Development; Inorganic Farming Practices; Soil Conservation; Inputs Access, Agronomic Practices, Processing, Land Preparation Technique, Improved Seedlings and Farm Record Keeping factors. Among other recommendations, the study recommended incorporation of extension services for physically challenged farmers into Agricultural Development Programme (ADP).

Keywords: Agriculture, Information needs, Physically challenged farmers, Leprosy

\section{Introduction}

About $15 \%$ of the world's population, or one billion people, live with disabilities (United Nations, 2012). Within the past decades, adult education and extension programmes have began to focus on adults with disabilities (Fall, 2008). Within the past decades, adult education and extension programmes have began to focus on adults with disabilities (Fall, 2008). Van and Frontier (2000) observed that there have been shortcomings in providing information to physically challenged farmers who are generally illiterate and 
relatively remote from formal sources of information such as extension stations and libraries. The need for extension information arises as a result of changing technology which helps to boost agricultural productivity and its effect on changing the living conditions of the physically challenged.

The physically challenged farmers in Leprosy Hospital, Ekpene Obom are involved in intensive agricultural production to satisfy their daily needs since the government and other charity organizations may not be able to provide all their needs for comfortable living (Hospital Management Committee, 2007). The assessment of the extension needs of physically challenged farmers in Leprosy Hospital, Ekpene Obom, Etinan Local Government Area is therefore necessary if appropriate measures must be taken to get them involved in the path of change.

Over the years, our rural farmers, including the physically challenged, depend on indigenous or local knowledge for improved farming systems. Such knowledge (indigenous or local knowledge) refers to skills and experiences gained through oral tradition and practice over many generations (Norem, et al, 1988). Acquisition of such primitive skill by the physically challenged farmers in Leprosy Colony, Ekpene Obom, Etinan Local Government Area has not helped to improve agricultural production and standard of living. The continuous usage of primitive skills in their farming activities has made them prone to poor farm yield, new crop and animal diseases, resistant plant weeds and pests that attack farm crops (Obidike, 2011).

United Nations (2012) has shown that about one billion people (15\% of world's population) live with disabilities. Disabled persons make up an integral part of our society and also fight for their day-to-day survival just as every normal person does. One of the physically challenged (disabled) persons found in Akwa lbom State are the Leprosy patients (referred to as Pal patients in the study area) who have been transferred to Qua Iboe Leprosy Hospital, Ekpene Obom in Etinan Local Government Area. Most of them have been abandoned and/or rejected by their family members and loved ones.

Notwithstanding the condition of these physically challenged persons, they engaged in profitable activities, one of which is intensive agricultural production, inorder to meet up with the day-to-day challenges that they face and to become independent. Among the crops planted by these people are mainly vegetables such as pumpkin, waterleaf, cucumber and garden eggs; on a large area of land located within the hospital premises and the wetland in that community. They also plant root and tuber crops like cassava, yam and sweet yam. Their produce are sold to women traders who come from far places to purchase their produce in large quantities and retail in the market. Thus, these physically challenged farmers contribute to the sustenance of humanity through engagement in intensive agricultural production.

Despite their contributions to the society, they have been denied access to extension services on improved agricultural practices which would have gone a long way to boost their productivity. This may be associated with the myth nurtured by most people that by a mere contact with a leper, one is likely to contact the disease; thereby exposing these physically challenged persons to humiliation and discrimination (Davis, 2010). As a 
result, they have been neglected to continue in their little knowledge of agricultural practices which has resulted in poor living standards and partial or total dependence on charity for survival. It is for this reason that this study is carried out to address the following research questions: What are the sources of agricultural information available to the respondents in the study area? What are the respondents' level of access to agricultural information in the study area? What are the agricultural information needs of the respondents in the study area?

\section{Methodology}

The study was undertaken in Etinan Local Government Area of Akwa Ibom State. One of the villages in Etinan is Ekpene Obom where the Qua Iboe Leprosy Hospital is situated. The hospital was established in 1932 by Qua Iboe Mission (QIM) as a leprosy settlement, but has over the years developed into a full fledged hospital. The hospital is located at latitude $4^{\circ} 51$ ' $39^{\prime \prime}$ North, and longitude $7^{\circ} 49^{\prime} 13^{\prime \prime}$ East of the equator. It was first called a colony and later, a Rehabilitation and Training centre. The hospital presently has approximately 150 in patients and out-patients who have been given permanent place of residence within the hospital premises to aid proper medical checkup. Those living outside the hospital premises come in from time to time for treatment and checkup (Hospital Management Committee, 2007). A two-stage sampling procedure was used for the study. The first stage involved stratifying the physically challenged farmers into two groups. Group one was made up of patients presently on treatment (in-patients, having a total population of 48) and Group two was made up of patients who have been treated and discharged but were still living within the hospital premise (out-patients, having a total population of 102). The two groups were summed up to the total population of 150 patients. The second stage involved random selection of 35\% of respondents from each group resulting in 17 respondents from Group one and 36 respondents from Group two, summing up to a total sample size of 53 respondents. Data was obtained from primary source through the use of questionnaires and interview schedule. Data were analyzed using factor analysis and cluster analysis. Respondents were required to identify from the drawn list below, the sources of information available to them in their locality. 4 points likert scale was used to measure the sources of agricultural information (Major, Minor, Source, Not a Source), level of access to agricultural information (Very High, High, Low, Very Low) and agricultural information needs (Very Severe Need, Severe Need, Mild Need, Not a Need) of the respondents from the highest to the lowest.

\section{Results and Discussion}

\section{Sources of agricultural information}

In examining the sources of agricultural information available to the respondents, the data set on sources of agricultural information was further subjected to factor analysis with fourteen (14) variables. Two major dimension of sources of agricultural information were derived through the application of varimax method of factor analysis from Table 1 . The eigen values were above unity. Communalities associated with the variables were high, indicating that the variables used in the study were appropriate and relevant to the sources of agricultural information as the variables clustered in two dimensions. 
Together, the two factors (dimensions) explained $61 \%$ of the total variance contained in the original data and were interpreted as composite indicators defining sources of agricultural information available to the respondents in the study area. Two underlying dimensions (i.e. factor loadings) were presented in Table 1. These are:

Factor 1: Individual contact method factor: This factor or component emerged as the most important dimension and accounted for $42.42 \%$ of the total variables in the data set of the 14 variables used in the study, two (2) had high positive loading on it. They included friends (.763) and neighbours (.751). Based on the dominance of variables associated with Individual Contact Method of information dissemination, factor one was named "Individual Contact Factor".

\section{Factor 2: Mass Contact Factor}

This factor or component accounted for $18.34 \%$ of the total variance in the data set of the fourteen (14) variables used in the study, two (2) variables loaded highly and positively on it. The variables were radio (.761) and television (.596). Because of the dominance of mass contact dissemination variables, factor 2 was named "Mass Contact Factor".

\section{Table 1: Rotated component matrix of sources of agricultural information}

\begin{tabular}{|c|c|c|c|c|}
\hline $\mathbf{S} / \mathbf{N}$ & Variables & Factor 1 & Factor 2 & Communalities \\
\hline (i) & Extension workers & & & .858 \\
\hline (ii) & Community Libraries & & & .801 \\
\hline (iii) & Radio & & .761 & .882 \\
\hline (iv) & Television & & .596 & .785 \\
\hline (v) & Film show & & & .955 \\
\hline (vi) & Agricultural Pamphlets & & & .645 \\
\hline (vii) & $\begin{array}{l}\text { State and local government } \\
\text { Agricultural agencies }\end{array}$ & & & .877 \\
\hline (viii) & Newsletter & & & .965 \\
\hline (ix) & Posters & & & .908 \\
\hline$(\mathrm{x})$ & Exhibitions & & & .908 \\
\hline (xi) & Leaflets & & & .647 \\
\hline (xii) & World Wide Web (www) & & & .798 \\
\hline (xiii) & Friends & .763 & & .904 \\
\hline \multirow[t]{4}{*}{ (xiv) } & Neighbours & .751 & & .914 \\
\hline & Eigen value & 2.14 & 1.016 & \\
\hline & Percentage variance & 42.42 & 18.34 & \\
\hline & Cumulative \% & 42.42 & 61.00 & \\
\hline
\end{tabular}

\section{Level of access to agricultural information}

From Table 2, the cluster analysis grouped the respondents into four clusters or categories based on their levels of access to agricultural information. This implies that the initial 53 respondents in the study area could be adequately classified into four 
groups. In order to further determine the critical levels among the four categories of the respondents of the access to agricultural information index, each group was analyzed.

\section{Group 1: Very low accessed group}

The first group consisted of $35(66 \%)$ respondents as shown in table 4.12 . The features of this group were characterized with a very weak and low access to agricultural information with the lowest mean index stock (0.18) and this defined the magnitude of the need gap. Thus, this group was best in terms of level of access to agricultural information and could be termed the most vulnerable group.

\section{Group 2: Low accessed group}

The composition of group 2 was summarized in table 4.12 . This group had $15(28 \%)$ cluster membership with the mean stock of 0.24. By implication, members of this group had a weak and low access to agricultural information.

\section{Group 3: High accessed group}

From the summary statistics group mean score (table 2), group 3 had only 2 members with cluster mean stock of 0.58 . The overall accessibility index of this group was above average, hence, the accessibility index of members of this group were high. By implication, members of this group had high access to various agricultural information.

\section{Group 4: Very high accessed group}

Group 4 had only one-cluster membership as presented in table 4 . This group was characterized with a very high access to agricultural information with the highest mean index stock of 0.86 and thus stood out above other groups in agricultural information accessibility.

Table 2: Summary statistics of cluster levels of access to agricultural information

\begin{tabular}{llllll}
\hline Cluster & $\begin{array}{l}\text { Number of } \\
\text { cases }\end{array}$ & $\%$ & $\begin{array}{l}\text { Range of } \\
\text { stock }\end{array}$ & $\begin{array}{l}\text { Mean Index } \\
\text { Stock }\end{array}$ & Status level \\
\hline 1 & 35 & 66 & $0.01-0.25$ & 0.18 & Very Low \\
2 & 15 & 28 & $0.26-0.49$ & 0.24 & Low \\
3 & 2 & 04 & $0.50-0.73$ & 0.68 & High \\
4 & 1 & 02 & $0.74-0.96$ & 0.86 & Very High \\
Total & 53 & 100 & $0.01-96$ & 2.00 & \\
\hline
\end{tabular}

\section{Agricultural information needs}

In order to determine the dimension of information needs of the respondents in the study area, a set of thirty (30) information needs variables were subjected to factor analysis. A Q-mode factor analysis with an extraction method of principal component analysis and a rotation method of varimax with Kaiser normalization was applied to the variables. This operation produced nine major dimensions of information needs which were named relative to the high loadings of the thirty (30) information needs variables on Table 3 . The significant factors of information needs extracted account for $79.72 \%$ of the total variation in the data set, and hence have been named as follows:

\section{Factor 1: Customized innovations and self development factor}


This factor accounted for $25.9 \%$ of the total variation within the distribution of the information needs variables and of thirty (30) variables used in the analysis, five (5) loaded highly on this factor. These were: appropriate facilities/innovation suitable to the condition of farmers (.816), self-improvement on social interaction (.628), building self confidence (.607), access to farm credits (.609) and access to transport facilities (.604). This factor was the most important factor among the nine dimensions extracted. By implication, the most pressing needs in terms of information and education are centred around the five (5) variables in this factor. Due to the dominance of factors on suitable innovations and self-improvement variables, the factor was named customized innovation and self development factor.

\section{Factor 2: Inorganic farming practices factor}

Since variables within this factor were associated highly with inorganic farming practices, this factor was named "inorganic farming practices factor". Four variables loaded highly on this factor namely: application of herbicide and pesticide (.721), sources and side effect of herbicide and pesticide (.701), appropriate application of chemicals for seed dressing (.701), and crop disease treatment and control (.674). this factor accounted for $13.4 \%$ of the variation in the data set. It is the second most important factor.

\section{Factor 3: Soil conservation}

This factor was responsible for $8.70 \%$ of the variation in the distribution of the information need variables. The factor was named "Soil Conservation Factor" because it loaded positively and highly on two major variables that were associated with soil conservation. These variables were: control of soil erosion (.626) and improvement of soil fertility (619). This factor is the third most important factor of information needs in the study area.

\section{Factor 4: Inputs access factor}

Factor 4 has been named "input access factor" due to its high loading on purchase of improved seed varieties (.616). This factor accounted for $6.52 \%$ of the variation in the data set.

\section{Factor 5: Agronomic practice factor}

This factor accounted for $6.29 \%$ of the variation in the data set. Only one variable loaded highly on this factor. This factor was appropriate fertilizer application method and this factor associated highly with agronomic practice hence it was named "Agronomic Practice Factor".

\section{Factor 6: Processing factor}

This factor has been named so due to the high positive loading on value chain addition to harvested farm produce (.716). This accounted for $6.08 \%$ of the variation in the data set.

\section{Factor 7: Land preparation techniques factor}

One variable loaded highly on this factor. This variable was improved land preparation techniques (.714) hence; it was named "Land Preparation Technique Factor". It accounted for $4.63 \%$ of the variation in the data set.

\section{Factor 8: Improved seedlings factor}

This factor accounted for $4.15 \%$ of the variation in the data set. It loaded high on only one variable (improved seedling i.e .601) hence it was named "improved seedlings factor".

\section{Factor 9: Farm record keeping factor}

This factor was the least factor, it accounted for only $3.93 \%$ of the variation in the data set. It loaded highly on farm record keeping variable hence it was named "farm record keeping factor". 
Table 3: Rotated component matrix of agricultural information needs 


\begin{tabular}{|c|c|c|c|c|c|c|c|c|c|c|c|}
\hline $\begin{array}{l}\mathbf{S} / \\
\mathbf{N}\end{array}$ & $\begin{array}{l}\text { Agricultural } \\
\text { Information Needs }\end{array}$ & F1 & F2 & F3 & F4 & F5 & F6 & F7 & F8 & F9 & Communalities \\
\hline $\mathrm{i}$ & $\begin{array}{l}\text { Application of } \\
\text { herbicides and } \\
\text { pesticides }\end{array}$ & & .721 & & & & & & & & \\
\hline ii & $\begin{array}{l}\text { Sources and side } \\
\text { effects of herbicides } \\
\text { and pesticides }\end{array}$ & & .701 & & & & & & & & .702 \\
\hline iii & $\begin{array}{l}\text { Better crop rotation } \\
\text { practices }\end{array}$ & & & & & & & & & & .687 \\
\hline iv & $\begin{array}{l}\text { Appropriate fertilizer } \\
\text { application methods }\end{array}$ & & & & & .814 & & & & & .861 \\
\hline v & $\begin{array}{l}\text { Types of soil and best } \\
\text { soil type for planting }\end{array}$ & & & & & & & & & & .805 \\
\hline Vi & Improved seedlings & & & & & & & & .601 & & .883 \\
\hline vii & $\begin{array}{l}\text { Crop disease } \\
\text { treatment and control }\end{array}$ & & .674 & & & & & & & & .828 \\
\hline viii & $\begin{array}{l}\text { New methods of crop } \\
\text { preservation }\end{array}$ & & & & & & & & & & .744 \\
\hline Ix & $\begin{array}{l}\text { Improvement of soil } \\
\text { fertility }\end{array}$ & & & .619 & & & & & & & .862 \\
\hline$x$ & Control of soil erosion & & & .626 & & & & & & & .711 \\
\hline$x i$ & $\begin{array}{l}\text { Appropriate seed } \\
\text { dressing chemicals }\end{array}$ & & .634 & & & & & & & & .853 \\
\hline Xii & $\begin{array}{l}\text { Improved land } \\
\text { preparation techniques }\end{array}$ & & & & & & & .714 & & & .728 \\
\hline Xiii & $\begin{array}{l}\text { Sales timing of } \\
\text { produce }\end{array}$ & & & & & & & & & & .746 \\
\hline Xiv & $\begin{array}{l}\text { Choice of crops to } \\
\text { grow at different } \\
\text { seasons }\end{array}$ & & & & & & & & & & .863 \\
\hline$x v$ & $\begin{array}{l}\text { Improved harvesting } \\
\text { methods for various } \\
\text { crops }\end{array}$ & & & & & & & & & & .753 \\
\hline xvi & Access to farm credit & .609 & & & & & & & & & .891 \\
\hline $\begin{array}{l}\text { Xvi } \\
\mathrm{i}\end{array}$ & $\begin{array}{l}\text { Access to transport } \\
\text { facilities }\end{array}$ & .604 & & & & & & & & & .906 \\
\hline $\begin{array}{l}\text { Xvi } \\
\text { ii }\end{array}$ & $\begin{array}{l}\text { Purchase of improved } \\
\text { seed varieties }\end{array}$ & & & & & & & & & & .766 \\
\hline xix & $\begin{array}{l}\text { Determination of } \\
\text { current market prices } \\
\text { for farm produce }\end{array}$ & & & & & & & & & & .712 \\
\hline$x x$ & Farm record keeping & & & & & & & & & .600 & .795 \\
\hline$x x i$ & $\begin{array}{l}\text { Current marketing } \\
\text { techniques }\end{array}$ & & & & & & & & & & .763 \\
\hline xxii & $\begin{array}{l}\text { Appropriate seed rate } \\
\text { and plant spacing }\end{array}$ & & & & & & & & & & .790 \\
\hline $\begin{array}{l}x x i i \\
i\end{array}$ & $\begin{array}{l}\text { Building self } \\
\text { confidence }\end{array}$ & .607 & & & & & & & & & .601 \\
\hline$x x i$ & Information and & & & & & & & & & & .803 \\
\hline $\mathrm{v}$ & $\begin{array}{l}\text { Communication } \\
\text { Technology }\end{array}$ & & & & & & & & & & \\
\hline$x x v$ & $\begin{array}{l}\text { Formation of farmers' } \\
\text { co-operative }\end{array}$ & & & & & & & & & & .876 \\
\hline $\begin{array}{l}x x v \\
i\end{array}$ & $\begin{array}{l}\text { Appropriate } \\
\text { facilities/innovations to } \\
\text { suit the condition of } \\
\text { farmers }\end{array}$ & .816 & & & & & & & & & .726 \\
\hline $\begin{array}{l}x x v \\
i i\end{array}$ & $\begin{array}{l}\text { Self-improvement on } \\
\text { social interaction }\end{array}$ & .628 & & & & & & & & & .858 \\
\hline $\begin{array}{l}x x v \\
\text { iii }\end{array}$ & $\begin{array}{l}\text { Value chain addition to } \\
\text { harvested farm } \\
\text { produce }\end{array}$ & & & & .616 & & .716 & & & & .873 \\
\hline $\begin{array}{l}x x i \\
x\end{array}$ & $\begin{array}{l}\text { Solution to problem of } \\
\text { pest hazards }\end{array}$ & & & & & & & & & & .932 \\
\hline \multirow[t]{4}{*}{$x x x$} & $\begin{array}{l}\text { Weed control } \\
\text { measures }\end{array}$ & & & & & & & & & & .883 \\
\hline & Eigen value & 7.776 & 4.047 & 2.610 & 1.955 & 1.888 & 1.825 & 1.389 & 1.246 & 1.179 & \\
\hline & Percentage Variance & 25.93 & 13.49 & 8.70 & 6.52 & 6.29 & 6.08 & 4.63 & 4.15 & 3.93 & \\
\hline & Cumulative $\%$ & 25.93 & 39.42 & 48.12 & 54.34 & 60.93 & 67.01 & 71.64 & 75.79 & 79.72 & \\
\hline
\end{tabular}




\section{Conclusion and Recommendations}

The study concluded that factor analysis performed on the fourteen (14) sources of agricultural information yielded two (2) dimensions namely Individual Contact and Mass Contact factors; these accounted for $61 \%$ of the variation. Accessibility to agricultural information was low. Cluster analysis further grouped the respondents into four cluster levels (very high, high, low and very low accessed groups) in terms of access to agricultural information, with the very low accessed group consisting majority $(66 \%)$ of the respondents. A factor analysis was also performed for the thirty (30) agricultural information need variables. This operation produced nine (9) factors namely; Customized Innovation and Self Development; Inorganic Farming Practices; Soil Conservation; Inputs Access, Agronomic Practices, Processing, Land Preparation Technique, Improved Seedlings and Farm Record Keeping factors. Based on the study, the following recommendations are made:

- Policy makers should ensure that agricultural education and extension programmes are upgraded and that training activities incorporate physically challenged persons in their programmes

- Effective information, education and communication strategies that will suit the conditions of physically challenged persons should be designed.

- Extension staff need to be retrained on approaches of reaching out to physically challenged persons.

- $\quad$ There should be improved visit of extension workers and also State and Local Government Agencies inorder to educate farmers on improved and new agricultural technologies/innovations.

\section{References}

Davis, G. (2010): "Physically Disabled". http:/www.helium.com>Home>Society \&Lifestyle $>$ Ethnicity\& Gender $>$ Ethnicity \& Gender (other). $17^{\text {th }}$ February, 2013.

Fall, T. S. (2008): "Working with Persons with Disabilities in Agriculture and Extension Education" www.adulteducation.wikibook.us/index/ph. 17 ${ }^{\text {th }}$ February, 2013.

Hospital Management Committee (2007): "A Brief Pictorial History of the Qua Iboe Leprosy Hospital and the Rehabilitation Programme". Akwa Ibom State, pp. 5 -6.

Norem, R. H., Yode, R., Martin, Y. (1988): "Indigenous Agricultural Knowledge and Gender Issues in Third World Agricultural Development". Prepared for the Joint Meeting of the Society of Social Studies of Science and the European Association of Science and Technology.

Obidike, N. A. (2011): "Rural Farmers' Problems Accessing Agricultural Information: A Case Study of Nsukka Local Government Area of Enugu State, Nigeria". Nnamdi Azikiwe Library, University of Nigeria, Nsukka. Library Philosophy and Practice 2011. 
United Nations (2012): "Removing Barriers to Create an Inclusive and Accessible Society for all”. International Day of Persons with Disabilities.

Van, C. L., and Frontier, F. (2000): "National Agricultural and Rural Knowledge and Information System (NARKIS): a Proposed Component of the Uganda National Agricultural Advisory Service (NAADS)". Food and Agricultural Organization Pp 22. 